\section{SOI: $\underline{1.1 / \mathrm{TAS}}$ DOI: $\underline{10.15863 / \mathrm{TAS}}$ International Scientific Journal Theoretical \& Applied Science}

p-ISSN: 2308-4944 (print) e-ISSN: 2409-0085 (online)

Year: $2015 \quad$ Issue: 03 Volume: 23

Published: $30.03 .2015 \quad \underline{\text { http://T-Science.org }}$

SECTION 11. Biology. Ecology. Veterinary.
Vladimir Nikolaevich Sorokopudov Doctor of Agricultural Sciences, professor, All-Russian Breeding and Technological Institute of Horticulture and Nursery, Moscow, Russia sorokopudov2015@yandex.ru

Thi Chuc Nguyen

PhD, Faculty of Forestry, Bryansk State Academy of Engineering and Technology, Bryansk, Russia chucnt1987@gmail.com

Svetlana Nikolayeva Shlapakova doctor of biological sciences, associate professor, Faculty of Forestry, Bryansk State Academy of Engineering and Technology, Bryansk, Russia shla-svetlana@yandex.ru

Thi Bich Thuy To master, teacher, Ho Chi Minh City University of physical education and sports, Ho Chi Minh, Viet Nam thuythuythuy@gmail.com

\title{
SOME FEATURES OF THE SPECIES OF THE GENUS JUGLANS L IN THE CONDITIONS OF BRYANSK OBLAST
}

\begin{abstract}
The genus Juglans, family Juglandaceae, comprises several species. It is widely distributed throughout the world. Green walnuts, shells, seeds, barks, and leaves are used in the pharmaceutical and cosmetic industries. Leaves are easily available in abundant amounts. The analysis was conducted for several purposes. Firstly, the elemental compositions of various parts of the leaves and immature fruits of four species of the genus Juglans L, growing in the conditions of Bryansk region was determined. Ten elements were detected by using electron-ion raster scanning microscope "Quanta 200 3D» in nanocenter NIU "BSU" and percentages of macronutrients and micronutrients in the leaves and immature fruits were determined. The analysis was also conducted to determine quantification of various substances: flavonoids, organic acids, vitamin $C$, antioxidant activity, dry matter, chlorophyll, carotenoid, free and bound water. This data can be used in the pharmaceutical industry. Secondly, the morphology and anatomy of the leaf and water-holding capacity of four species of the genus Juglans $L$ were also identified. Therefore, this result can prove the difference among the species of the genus Juglans $L$.

Key words: Anatomy, species of the genus Juglans L, leaf, chlorophyll, immature fruit, chemical composition. Language: English

Citation: Sorokopudov VN, Nguyen TC, Shlapakova SN, To TBT (2015) SOME FEATURES OF THE SPECIES OF THE GENUS JUGLANS L IN THE CONDITIONS OF BRYANSK OBLAST. ISJ Theoretical \& Applied Science 03 (23): 49-54.

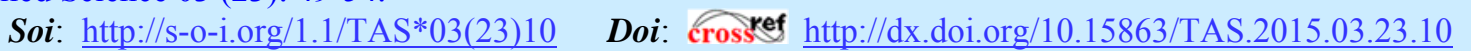

\section{Introduction}

It is well known that the species of the genus Juglans L are valuable fruit trees example [6, p.95$98 ; 15]$. They have high economic value. They are widely used in medical and pharmaceutical industries. The fruits contain up to $76 \%$ fat, $22 \%$ protein and carbohydrates, as well as vitamins A, C, $\mathrm{E}$ and $\mathrm{F}$ [11]. Activated carbons were prepared from walnut shells. Foliage, barks, roots and green shells are used for dyeing fabrics (wool, silk, yarn), as well as for hair coloring [9, p.212-214]. Vitamin concentrate is prepared from immature fruits $[3 ; 12$ p.54]. Therefore, it is necessary to conduct a study of the chemical compositions of leaves and immature fruits to search for an additional source of medicinal plants. Additionally, species of the genus Juglans L are moisture-loving plants, but they differ in drought resistance [13]. Drought resistance is determined in the driest growing season [14]. We use physiological methods to identify drought resistance features of the species of the genus Juglans L in the conditions of the Bryansk region.

\section{Materials and methods}

The leaves and immature fruits of four species of the genus Juglans L were used as research materials: walnut (Juglans regia), Manchurian walnut (Juglans mandshurica), back walnut (Juglans nigra), butterwalnut (Juglans cinerea). Anatomical study and elemental compositions of the leaves and immature fruits were carried out using the ionscanning electron microscope. Anatomy and morphological parameters of the epidermal cells of 
the leaves of various species of the genus Juglans L were studied using the SEM Quanta 200 3D, the Carl Zeiss microscope and the program VideoTest 5.0. Chemical compositions of the leaves and immature fruits were analyzed following the instructions in GOST 5900-73 (for dry matter and water content ), differential spectrophotometry (for flavonoid content), in titrimetry (content of ascorbic acid; content of free organic acids), in the Levantalya method (for determination of antioxidant activity of plant materials), in spectrophotometry (for chlorophyll content) in refractometer (for content of free and bound water). Drought resistance was evaluated by the degree of damage of the leaves.

\section{Results and discussions}

1. The chemical composition of leaves and immature fruits of some species of the genus Juglans $\mathrm{L}$ in the conditions of Bryansk region.
The data obtained allows us to conclude that the leaves of four species of the genus Juglans L contain a large amount of magnesium, which has a calming effect on the brain, and a large amount of this macro -element promotes anti-stress action [9, p.33-44]. The content of magnesium $1.18 \%$ (Table - 1 ) is determined in the walnut Juglans nigra. The leaves of the four species of the genus Juglans L also contain a large amount of calcium. It is well known that the species of the genus Juglans L have the properties of drought resistance and winter hardiness [10], which are enhanced due to the presence of high calcium content.

Elemental composition of the leaves of four species of the genus Juglans L (Wt\%)

Table 1

\begin{tabular}{|l|l|l|l|l|}
\hline Element & Juglans regia & J.nigra & J.mandshurica & J.cinerea \\
\hline$C$ & 46.34 & 42.65 & 40.75 & 61.93 \\
\hline$O$ & 48.60 & 53.92 & 55.89 & 36.01 \\
\hline$M g$ & 0.92 & 1.18 & 0.84 & 0.28 \\
\hline$A l$ & - & 0.17 & 0.15 & 0.13 \\
\hline$P$ & 0.15 & 0.18 & - & - \\
\hline$K$ & 0.83 & 0.75 & 1.02 & 0.51 \\
\hline$C a$ & 0.80 & 1.15 & 0.96 & 0.94 \\
\hline$S i$ & 2.35 & - & 0.39 & 0.19 \\
\hline
\end{tabular}

This is explained by the role of calcium because calcium and magnesium are the basis of pectin of medial plates of cells (intercellular substance) in the plant body. Calcium ensures the integrity of cell membranes has a water retention capacity of protoplasm, involves in the construction of the cell wall of plants; increases plant tissues' hardness and improves plants' endurance. Its contents are $0.15 \%$ (Table-1), which is found in the black walnut leaves and $4.03 \%$ in the Manchurian walnut immature fruits (Table 2). It is known that calcium is an essential element in the human body. It plays an important role in the regulation of the blood clotting, in the heart rhythm regulation. It also plays a vital role in immune processes, in the synthesis and enzyme works [11]. Being present in every cell of the body, calcium regulates the reproduction of cells and protein synthesis. For these reasons, it is important to find affordable medicinal raw materials with a high content of calcium. A large amount of potassium is also found in the leaves and immature fruits. The content of potassium is $0.51-1.02 \%$ (Table 1 ) in the leaves and its content is revealed from $2.55 \%$ $3.87 \%$ (Table-2) in the immature fruit. Potassium is involved in the regulation of cellular osmotic potential. Potassium plays an important role in the drought resistance and winter hardiness. It also plays an essential role in the regulation of water balance and the process of normalization of cardiac rhythm [9, p.33-44]. It can be suggested that the leaves and immature fruits of the genus Juglans L are an available source of calcium, potassium and magnesium due to the high content of potassium according to our data (Table 1-2). Silicon is found in all four species of the genus Juglans L and its content is up to $2.34 \%$ in the leaves of Juglans regia that increases plant resistance to powdery mildew. Iodine is also found in the immature fruits. Tincture of pericarp is recommended in the treatment of hyperthyroidism [7, p.121-123]. 
Elemental compositions of immature fruits of four species of the genus Juglans $L(\mathrm{Wt} \%)$

Table 2

\begin{tabular}{|c|c|c|c|c|}
\hline Element & Juglans regia & J.nigra & J.mandshurica & J.cinerea \\
\hline $\mathrm{C}$ & 56.71 & 52.84 & 52.08 & 56.70 \\
\hline $\mathrm{O}$ & 38.08 & 42.22 & 38.82 & 38.54 \\
\hline $\mathrm{Mg}$ & 0.28 & 0.12 & 0.55 & 0.21 \\
\hline $\mathrm{Al}$ & 0.03 & 0.17 & 0.16 & 0.09 \\
\hline $\mathrm{P}$ & 0.52 & 0.28 & 0.20 & 0.40 \\
\hline $\mathrm{K}$ & 3.87 & 3.34 & 2.85 & 2.55 \\
\hline $\mathrm{Ca}$ & - & 0.44 & 4.03 & 1.23 \\
\hline $\mathrm{Si}$ & 0.08 & 0.13 & 0.08 & 0.05 \\
\hline $\mathrm{S}$ & 0.27 & 0.21 & 0.19 & 0.23 \\
\hline I & 0.14 & 0.24 & 0.86 & - \\
\hline
\end{tabular}

The data obtained allow us to conclude that the leaves and immature fruits of all species of the genus Juglans growing in the Bryansk region contain various biological compounds: flavonoids, organic acids (up to $3,838 \%$ in immature fruits of the walnut Juglans mandshurica), ascorbic acid (Table 3-4).

The quantitative content of several compounds in the leaves of four species of the genus Juglans $\mathbf{L}$

\begin{tabular}{|l|c|c|c|c|}
\hline Class of substances & Juglans regia & Juglans nigra & $\begin{array}{l}\text { Juglans } \\
\text { mandshurica }\end{array}$ & Juglans cinerea \\
\hline Free water (\%) & $56.345 \pm 3.229$ & $41.575 \pm 4.962$ & $51.639 \pm 1.648$ & $45.610 \pm 1.514$ \\
\hline Bound water (\%) & $15.975 \pm 2.353$ & $18.705 \pm 1.414$ & $19.112 \pm 1.868$ & $17.818 \pm 1.707$ \\
\hline Dry matter (\%) & $27.679 \pm 1.228$ & $34.720 \pm 4.962$ & $29.248 \pm 1.689$ & $36.571 \pm 1.5149$ \\
\hline Flavonoid (\%) & $2.25 \pm 0.08$ & $1.424 \pm 0.09$ & $1.894 \pm 0.10$ & $2.351 \pm 0.07$ \\
\hline Organic acid (\%) & 3.474 & 3.334 & 3.824 & 3.012 \\
\hline Ascorbic acid (\%) & $0.156 \pm 0.012$ & $0.104 \pm 0.007$ & $0.119 \pm 0.019$ & $0.061 \pm 0.008$ \\
\hline $\begin{array}{l}\text { Antioxidant } \\
\text { activity (мг/л) }\end{array}$ & 224 & 288 & 184 & 114 \\
\hline
\end{tabular}

Table 4

The quantitative content of several compounds in the immature fruits of four species of the genus Juglans $L$

\begin{tabular}{|l|c|c|c|c|}
\hline & Juglans regia & Juglans nigra & $\begin{array}{l}\text { Juglans } \\
\text { mandshurica }\end{array}$ & Juglans cinerea \\
\hline Free water (\%) & $59.629 \pm 2.911$ & $42.710 \pm 2.763$ & $41.427 \pm 5.298$ & $43.729 \pm 1.474$ \\
\hline Bound water (\%) & $27.563 \pm 1.256$ & $35.250 \pm 1.386$ & $45.114 \pm 2.023$ & $38.589 \pm 1.253$ \\
\hline Dry matter (\%) & $12.807 \pm 1.911$ & $22.039 \pm 2.763$ & $13.458 \pm 1.298$ & $17.681 \pm 1.474$ \\
\hline Flavonoid (\%) & $1.689 \pm 0.12$ & $1.857 \pm 0.08$ & $2.051 \pm 0.11$ & $1.652 \pm 0.08$ \\
\hline Organic acid (\%) & 3.828 & 2.148 & 3.838 & 2.675 \\
\hline Ascorbic acid (\%) & $0.765 \pm 0.027$ & $0.811 \pm 0.018$ & $0.117 \pm 0.018$ & $0.745 \pm 0.017$ \\
\hline
\end{tabular}

Immature fruits of the walnut Juglans mandshurica contain a small amount of vitamin C. Fruits of other species contain sufficiently high amount of vitamin $\mathrm{C}$ and $0,811 \%$ vitamin $\mathrm{C}$ is found in immature fruits of the walnut Juglans nigra. To conclude that, unripe fruits of various species of the genus Juglans L can be used as a source of vitamin C to make jams and fortified wine [14]. The high 
content of bound water in the leaves and unripe fruits increases their resistance to unfavorable factors. Animal eating flavonoid-containing leaves have hypotensive, antispasmodic and anti-inflammatory effects [15].

2. Drought resistance of some species of the genus Juglans L. in the conditions of Bryansk oblast.

Stomata play an important role in adaptation processes in different conditions and also in the plant productivity. The stomatal apparatus of four species of the genus Juglans L has an anomotsitny type. Stomata are randomly arranged on the leaf surface. Guard cells dominated the principal cells of the epidermis is observed on the leaf surface of the walnut Juglans mandchurica. Stomata of the walnut Juglans regia, Juglans nigra, Juglans cinerea are located in the same level with the main cells of the epidermis (Fig. 1 to 4). Additionally, stomata are found only on the lower side of the leaf. The number of stomata per unit area on the leaf surface varies between 81-115. It depends on the type species. The highest number of stomata is observed on the leaf surface of the walnut Juglans cinerea, they also have the largest size of stomata (Table 5).

According to data obtained by studying of the structural features of the epidermis of the leaf four species of the genus Juglans L that cells of the abaxial side are smaller than the cells of the adaxial side of the leaf (Table 6). The shape of the upper epidermal cells is: quadrilateral and polygonal. These cells are densely arranged to each other, and the cells of the lower epidermis have a substantially quadrangular shape. The cells of the upper epidermis Juglans regia mostly have a quadrangular shape. The length of the epidermal cells is greater than their width. Two types of trichomes were found: simple and glandular trichomes. Glandular trichomes are found only on the veins.

Morphological parameters of the stomata of the lower epidermis of the leaf of four species of the genus Juglans L: * Accuracy in comparison with the Juglans regia (by Student's test $(p<0.05)$.

\begin{tabular}{|c|c|c|c|c|c|}
\hline Specie & Area $\left(\mu \mathrm{m}^{2)}\right.$ & Perimeter $(\mu \mathrm{m})$ & Length $(\mu \mathrm{m})$ & Width $(\mu \mathrm{m})$ & $\begin{array}{c}\text { Number of stomata } \\
/ 1 \mathrm{Mm}^{2}\end{array}$ \\
\hline Juglans regia & $300.10 \pm 7.26$ & $60.84 \pm 2.28$ & $23.10 \pm 2.90$ & $16.54 \pm 3.86$ & 89 \\
\hline Juglans nigra & $239.72 \pm 4.85^{*}$ & $50.51 \pm 3.28$ & $20.34 \pm 3.84$ & $14.87 \pm 2.53$ & 98 \\
\hline Juglans mandchurica & $228.48 \pm 15.71^{*}$ & $49.68 \pm 6.87^{*}$ & $20.13 \pm 2.44$ & $14,70 \pm 1.62$ & $115^{*}$ \\
\hline Juglans cinerea & $315.83 \pm 14.99$ & $66.56 \pm 8.39$ & $22.59 \pm 3.89$ & $17.89 \pm 2.56$ & 81 \\
\hline
\end{tabular}

Table 6

Morphological parameters of the epidermal cells of the leaf of four species of the genus Juglans L: * Accuracy in comparison with the Juglans regia (by Student's test $(p<0.05)$.

\begin{tabular}{|l|c|c|c|c|}
\hline Specie & Cell & Area $\left(\mu \mathrm{m}^{2)}\right.$ & $\begin{array}{c}\text { Length } \\
(\mu \mathrm{m})\end{array}$ & $\begin{array}{c}\text { Width } \\
(\mu \mathrm{m})\end{array}$ \\
\hline \multirow{3}{*}{ Juglans regia } & Upper epidermis & $289.25 \pm 28.39$ & $25.53 \pm 3.86$ & $18.09 \pm 2.08$ \\
\cline { 2 - 5 } & Lower epidermis & $189.73 \pm 20.96$ & $20.39 \pm 1.77$ & $14.53 \pm 3.93$ \\
\hline \multirow{3}{*}{ Juglans nigra } & Upper epidermis & $326.59 \pm 22.82^{*}$ & $28.72 \pm 5.54$ & $18.75 \pm 3.49$ \\
\cline { 2 - 5 } & Lower epidermis & $194.27 \pm 48.43^{*}$ & $21.52 \pm 4.63$ & $13.36 \pm 1.68$ \\
\hline \multirow{3}{*}{ Juglans mandchurica } & Upper epidermis & $319.19 \pm 20.52$ & $28.89 \pm 3.58$ & $19.05 \pm 3.75$ \\
\cline { 2 - 5 } & Lower epidermis & $191.32 \pm 27.26$ & $17.94 \pm 5.72$ & $14.64 \pm 4.77$ \\
\hline \multirow{2}{*}{ Juglans cinerea } & Upper epidermis & $300.89 \pm 20.82$ & $25.89 \pm 4.75$ & $20.75 \pm 2.89$ \\
\cline { 2 - 5 } & Lower epidermis & $184.57 \pm 40.23$ & $18.72 \pm 6.83$ & $12.39 \pm 2.78$ \\
\hline
\end{tabular}

The study of leaf morphology of some species of the genus Juglans L in the conditions of Bryansk region showed that leaf of the walnut Juglans nigra has the smallest size, while the leaf of the walnut Juglans mandchurica has the largest size (Table-7). 
Table 7

Morphological parameters of the leaf of four species of the genus Juglans L: * Accuracy in comparison with the Juglans regia (by Student's test $(\mathrm{p}<0.05)$.

\begin{tabular}{|l|c|c|c|c|}
\hline Specie & Juglans regia & Juglans nigra & Juglans mandchurica & Juglans cinerea \\
\hline Leaf length(cм) & $40.5 \pm 4.14$ & $40.75 \pm 4.13$ & $61.4 \pm 3.20^{*}$ & $43.7 \pm 2.99$ \\
\hline Leaf width (cм) & $28.8 \pm 2.70$ & $23.67 \pm 1.53$ & $32.4 \pm 2.30^{*}$ & $21.24 \pm 1.87$ \\
\hline Leaflet length $(\mathrm{cm})$ & $14.17 \pm 3.68$ & $9.92 \pm 1.81$ & $15.22 \pm 2.87$ & $10.45 \pm 1.78$ \\
\hline Leaflet width(cM) & $6.01 \pm 1.66$ & $2.91 \pm 1.24^{*}$ & $5.76 \pm 1.23$ & $4.73 \pm 0.62$ \\
\hline Leaflet area $\left(\mathrm{cm}^{2}\right)$ & $58.17 \pm 4.20$ & $17.67 \pm 3.25^{*}$ & $61.44 \pm 6.28$ & $34.95 \pm 5.68^{*}$ \\
\hline Number of leaflets & $7-9$ & $19-21$ & $15-17$ & $15-17$ \\
\hline Petiole length $(\mathrm{cm})$ & $9.3 \pm 2.16$ & $5.58 \pm 0.86$ & $10.8 \pm 2.04$ & $5.6 \pm 0.8$ \\
\hline
\end{tabular}

Qualitative and quantitative composition of pigments is considered as indicator of plant adaptation to environmental conditions. The amount of chlorophyll and carotenoid of four species of the genus Juglans L is decreased; this is due to adaptation of plants to high temperature and water shortages (Table-8). However, the amount of bound water is increased. The amount of bound water of the walnut Juglans mandchurica is not practically changed; it can be explained by the fact that their leaves are damaged by drought.

\section{Content of chlorophylls and carotenoids in the leaves of four species of the genus Juglans $L$.}

\begin{tabular}{|c|c|c|c|c|c|}
\hline & Specie & Juglans regia & Juglans nigra & $\begin{array}{c}\text { Juglans } \\
\text { mandchurica }\end{array}$ & Juglans cinerea \\
\hline \multirow{2}{*}{$\begin{array}{l}\text { Chlorophyll a (mg } \\
\text { / g) }\end{array}$} & 25.06 & 1.05 & 1.25 & 0.85 & 0.89 \\
\hline & 18.07 & 0.61 & 0.72 & 0.56 & 0.59 \\
\hline \multirow{2}{*}{$\begin{array}{l}\text { Chlorophyll b (mg } \\
\text { / g) }\end{array}$} & 25.06 & 0.37 & 0.35 & 0.34 & 0.33 \\
\hline & 18.07 & 0.25 & 0.27 & 0.31 & 0.21 \\
\hline \multirow{2}{*}{$\begin{array}{l}\text { Chlorophyll. } \mathrm{a}+\mathrm{b} \\
(\mathrm{mg} / \mathrm{g})\end{array}$} & 25.06 & 1.42 & 1.60 & 1.19 & 1.22 \\
\hline & 18.07 & 0.86 & 0.99 & 0.87 & 0.80 \\
\hline \multirow{2}{*}{$\begin{array}{l}\text { Carotenoid } \\
(\mathrm{mg} / \mathrm{g})\end{array}$} & 25.06 & 0.28 & 0.22 & 0.19 & 0.18 \\
\hline & 18.07 & 0.12 & 0.14 & 0.11 & 0.11 \\
\hline \multirow[t]{2}{*}{ Free water $(\%)$} & 25.06 & $56.35 \pm 3.23$ & $41.57 \pm 4.96$ & $51.64 \pm 1.65$ & $45.61 \pm 1.51$ \\
\hline & 18.07 & $45.73 \pm 2.14$ & $35.26 \pm 2.36$ & $40.30 \pm 1.88$ & $38.11 \pm 1.58$ \\
\hline \multirow[t]{2}{*}{ Bound water (\%) } & 25.06 & $15.97 \pm 2.35$ & $18.71 \pm 1.41$ & $19.11 \pm 0.87$ & $17.82 \pm 1.71$ \\
\hline & 18.07 & $25.86 \pm 3.02$ & $29.89 \pm 1.77$ & $20.52 \pm 1.78$ & $22.58 \pm 2.36$ \\
\hline
\end{tabular}

The results obtained from (Table-9) shows that the walnut Juglans mandchurica and Juglans cinerea are the greatest water loss but they are the least drought - resistant plants. Drought resistance was evaluated by the extent of the damage of the leaf on the four-point scale: 0 - No damage; 1 - Damage of the edges of leaves; 2- Damage to a significant part of the leaves (about half); 3- Damage to all leaves [1; 2].

Table 9

Characteristics of water-holding capacity of leaves and the relative extent of drought resistance of four species of the genus Juglan $\mathrm{L}$.

\begin{tabular}{|c|c|c|c|c|}
\hline \multirow{2}{*}{} & \multicolumn{2}{|c|}{ Water lost after leaf wilting, \% of water content } & \multirow{2}{*}{$\begin{array}{l}\text { Drought } \\
\text { resistance, point }\end{array}$} \\
\cline { 2 - 4 } & After 2 h. & After 4h. & After 6h. & \\
\hline Juglans regia & 8.05 & 17.23 & 24.35 & 0 \\
\hline Juglans nigra & 7.51 & 18.56 & 23.24 & 0 \\
\hline Juglans mandchurica & 20.25 & 45.67 & 65.35 & 1 \\
\hline Juglans cinerea & 15.25 & 28.77 & 55.11 & 1 \\
\hline
\end{tabular}




\section{Conclusions}

1. Leaves and immature fruits of four species of the genus Juglans L are highly valued due to their high content of calcium and potassium, magnesium, and vitamin $\mathrm{C}$ and high antioxidant activity. In conclusion, that they can be used as sources of additional medicinal herbs.
2. Four species of the genus Juglans L are drought resistant and winter resistant plants in the conditions of Bryansk region, due to high contain of calcium, potassium and magnesium.

3 The walnut Juglans regia, Juglans nigra are the most drought-resistant plants in the conditions of Bryansk region.

\section{References:}

1. Artamonov VI (1991) Amusing plant physiology.Agropromizdat, Russia: 124.

2. Artyushenko ZT (1990) Atlas of descriptive morphology of higher plants. Semia, Russia: 75.

3. Auth Thomas (1985) Walnut orchard management. Calif : 178.

4. Bavtut GA, Eremin VM, Zhigar MP (2001) Atlas of plant anatomy. Mn Uradzhay, Russia: 245.

5. Cordon RY, Smoljaninova LA, Haryuzova ED (1936) The walnut. XVII cultural flora of the USSR. Leningrad: 44-94.

6. Dayronas ZV, Kuleshov SA, Pshukova IV (2010) Phytochemical study of walnut leaves as a source of antioxidant agents. Chemistry of plant raw materials: 95- 98.

7. Gusev MV, Kamensky LA (2002) Biology. University of Moscow, Russia: 26.

8. Ivchenko SI, Rudenko VF (1976) Forest fruit plants: 121- 123 .
9. Ivashin DS, Katina ZF, Rybachuk IZ, Ivanov VS, Butenko LT (1971) Medicinal plants of Ukraine: 212-214.

10. Malinovsky VI (2004) Physiology of plants. Vladivostok, Russia: 33-44.

11. Medvedev SS (2004) Plant Physiology. St. Petersburg University, Russia: 210.

12. Nikolaev EA, Slavskii VA, Tishchenko VV (2007) Introduction and selection of walnut in Voronezhsoy region. Monograph .Voronezh state research : 152 .

13. Smolyanskii BL, Abramov JI (1985) Handbook of clinical nutrition. Stereotype. LA: Medicine: 54.

14. Shchepotev FL, Richter A, Pavlenko FA (1978) Forest cultures and others: 256.

15. Tatarintseva AC (1981) Selection fruit crops: 348.

16. Yakushkina NI (2004) Physiology of plants. Vlados, Russia: 105. 